\title{
Deleuzian (Re)interpretation of Zhu Xi
}

\author{
Margus OTT*
}

\begin{abstract}
I propose an interpretation of Zhu Xi 朱喜 (1130-1200) seen through the ontology of Gilles Deleuze. Zhu Xi is one of the most prominent Chinese philosophers, the figurehead of the so-called Neo-Confucian school, and Deleuze is arguably one of the most important Western philosophers of the twentieth century. Both philosophers presented an ontology of differentiation, whose main aspects or stages I try to analyse in the paper: Deleuze's notions of the virtual, dark precursor, field of individuation, intensities and the actual; and parallel to these, Zhu Xi's notions of the veins ( $l i$ 理), supreme ultimate (taiji 太極), energy ( $q i$ 氣), and things ( $w u$ 物). It is argued that a Deleuzian (re)interpretation of $\mathrm{Zhu} \mathrm{Xi}$ is possible and that it may open new tools of analysis for studying Chinese philosophy as well as create a conceptual space that can bring together concepts and practices from different traditions.
\end{abstract}

Keywords: Zhu Xi, Deleuze, comparative philosophy, ontology, virtual, dark precursor, actual, intensities

\section{Deleuzovska reinterpretacija Zhu Xija}

\section{Izvleček}

Predlagam novo interpretacijo Zhu Xija 朱喜 (1130-1200) skozi optiko ontologije Gillesa Deleuza. Zhu Xi je eden najbolj znanih kitajskih filozofov in osrednji predstavnik tako imenovane neokonfucijanske šole, Deleuze pa je nedvomno eden najpomembnejših zahodnih filozofov dvajsetega stoletja. Oba teoretika sta ustvarila ontologiji, ki temeljita na razlikovanju. Osrednje vidike oziroma stopnje obeh ontologij in ustreznih tipov razlikovanja bom analiziral v pričujočem članku. Pri tem se bom osredotočil na Deleuzove ideje virtualnega, temačnega predhodnika, polja individuacije, intenzivnosti ter aktualnosti. Vzporedno s temi idejami bom obravnaval tudi Zhu Xijeve pojme žil ( $l i$ 理), skrajnega pola (taiji 太極), energije ( $q i$ 氣) in stvari ( $w u$ 物). Trdim, da je deleuzovska (re)interpretacija Zhu Xija možna, da nam lahko nudi nova orodja analize za študij kitajske filozofije ter da lahko ustvari nov konceptualni prostor, v katerem bo mogoče združevati ideje in prakse različnih tradicij.

Ključne besede: Zhu Xi, Deleuze, primerjalna filozofija, ontologija, virtualnost, temačni predhodnik, aktualnost, intenzivnosti

* $\quad$ Margus OTT, Tallinn University, Xiamen University.
E-mail address: motlus@gmail.com

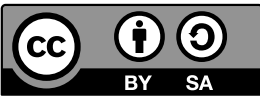




\section{Introduction ${ }^{1}$}

Zhu Xi 朱喜 (1130-1200) is one of the most eminent Chinese philosophers, the figurehead of the Neo-Confucian school that in the eleventh century, after several centuries of Buddhist and Daoist prominence, tried to revive ancient Confucianism, in a manner somewhat similar to the way the Renaissance in Europe a few centuries later returned to the ideas of Greco-Roman Antiquity. Another similarity to the Renaissance lies in the fact that although Neo-Confucianism promoted Confucianism, it was in fact a strongly syncretistic movement (like its European counterpart), having absorbed important influences from Buddhism and Daoism, both in theory (for instance, interest in cosmological matters) and practice (for instance, “calm sitting” jingzuo 靜坐 meditation).

It should first be noted that the term "Neo-Confucianism" is a Western notion that is not used in Chinese and was not the movement's autonym. In China, the movement is called "the study of Dao" (Daoxue 道學), "the study of the veins"2 (lixue 理學) or by some other term. However, the school did intend to revive Confucius' teaching, so the term Neo-Confucianism is not misleading (for further discussion, see Makeham 2010, x-xiv).

$\mathrm{Zhu} \mathrm{Xi}$ is the most prominent representative of Neo-Confucianism, the leading figure of the so-called Cheng-Zhu school (named after the brothers Cheng: Cheng Hao 程影, 1032-1085, and Cheng Yi 程頣, 1033-1107, and Zhu Xi himself). In place of a previous, more extensive canon of books, he selected a more reduced canon of the "Four Books" (Analects, Great Learning, Doctrine of the Mean, and Mencius) which, together with Zhu Xi's own comments, were to become the basis of Imperial examinations for nearly six hundred years, from 1313 to 1905. So, his influence on Chinese philosophy is hard to overestimate.

In his ontology Zhu Xi synthesized the concepts of veins ( $l i$ 理), energy ( $q i$ 氣) ${ }^{3}$ and supreme ultimate (taiji 太极) that had been discussed by his predecessors Zhou Dunyi 周敦頣 (1017-1073), Zhang Zai 張載 (1020-1078), and brothers Cheng. Already in Zhu Xi's lifetime his students and contemporaries were puzzled by how exactly veins and energy were related to each other, or what was the status of the supreme ultimate, and these questions have remained topics of scholarly debate until today. The paper uses Deleuze's philosophy, and more precisely the philosophy of the actualization of the virtual presented

\footnotetext{
1 This project was supported by the Estonian Research Council grant PRG319.

2 For this translation of the term, see below, section "Articulation and Energy".

3 For the translation of this term, see below, section "Articulation and Energy".
} 
in the Difference and Repetition (1994), to (re)interpret ${ }^{4}$ Zhu Xi's notions and their relations.

The aim of the paper is not so much to show that the Deleuzian concepts in question are the "same" as Zhu Xi's, but rather to show that the two thinkers can be brought fruitfully together and that their incongruity due to temporal, spatial and cultural differences need not be an obstacle, but on the contrary that these two disparate "images of thought" 5 might, by their very incongruity, open a sense of depth in thought, just as the perception of depth in the visual field is formed on the basis of two incongruous images from the two eyes ( $\left.\mathrm{DR}^{6}, 51\right)$. This disparity between the two cannot be fully worked out in a short paper like this, but what's possible in the limited space might serve as a guiding principle in comparative philosophy in general.

\section{Deleuze's Ontology: Virtual, Intensive, Actual}

One of Deleuze's great contributions to the philosophy of difference and differentiation was to get rid of the problem of the one and the many (DR, 182sqq). To show that the question is not how one becomes many and how the many are (or are not) one, but that being is always a multiplicity and that differentiation can be described in terms of different types of multiplicity. It is never possible to produce multiplicity from the absolute One; all genetic processes must contain a multiplicity all along. ${ }^{7}$

4 Every interpretation is already a reinterpretation, a new contextualization, so their difference is rather of degree than all-or-nothing.

5 "Image of thought" is Deleuze's notion and refers to what is already presupposed when one starts to think (Lambert 2012, 1). This notion underwent a transformation: while in the earlier books Deleuze wanted to propose a "thought without image", in his later works he rather wanted to propose a "new image of thought" (see Dronsfield 2012).

6 DR refers to the English translation of Difference and Repetition (Deleuze 1994).

7 The problem with the "one" and the "many" in the Western tradition is that they are "concepts of the understanding which make up the overly loose mesh of a distorted dialectic which proceeds by opposition" (DR, 182). The main target is Hegel: being, non-being, becoming, etc.: "Can we believe that the concrete is attained when the inadequacy of an abstraction is compensated for by the inadequacy of its opposite?" (ibid.) It applies also to Platonic interpretations: the notion of multiplicity "denounces simultaneously the One and the many, the limitation of the One by the many and the opposition of the many to the One" (DR, 302). Platonic idealism: the One is the "same", and the many are the "similar", the many represent and resemble the One. Multiplicity, instead, replaces both the one and the many, "Everywhere the differences between multiplicities and the differences within multiplicities replace schematic and crude oppositions. Instead of the enormous opposition between the one and the many, there is only the variety of multiplicity." $(\mathrm{DR}, 182)$ 
Deleuze first worked out the idea of different orders of differences in relation to Bergson, who had made a distinction between a space-like multiplicity, the elements of which are juxtaposed with each other, and a duration-like multiplicity, the elements of which interpenetrate each other. It is not a distinction between space and time, but between chrono-metric spacetime, whose metric lies outside of the elements involved (e.g. yardstick, a chronometer), and durational-topological spacetime, where the elements contain their metric in themselves. In the first case the distances and intervals are defined by some conventional unit, in the second case what matters is the type of relations between the elements (ordinary and singular points; saddles, nodes; etc.; see also DeLanda 2002). The first is the objectified space-time, the second is an experienced spacetime. It is clear that the elements I perceive in my surroundings or that I can distinguish in the memory of my temporal existence are not outside each other but form a field with an inner articulation whose elements are defined by their relations: every passing moment forms a whole with the rest of my memory (the Bergsonian "memory cone" that involves all my past experience) and every element of my perceptual field has relations to others (for instance, being on the foreground or background, being attractive or repulsive, eliciting certain interactions like a cup on my table, etc.).

Against this Bergsonian background, Deleuze creates a more detailed account of differentiation in the Difference and Repetition. The basis of differentiation is a virtual multiplicity that Deleuze describes in terms borrowed from mathematics. The virtual multiplicity has differential elements (e.g. phonemically relevant features like voiced/voiceless, labial/dental/guttural, etc.) that are reciprocally determined in differential relations (for example, the structure of all the relevant phonemic relations) that form singularities or attractors (phonemes). Deleuze calls this state of multiplicity (e.g. phonemic differences) perplication (for different "plications" see DR, 280-81).

It might be argued that formally similar occurrences of the One and the Many in the Chinese tradition-for example Laozi $§ 42$ (cited below, section "Background in Chinese Tradition: Genesis by Differentiation"): "one begets two, two beget three, three beget the myriad things" - sit in a different context. First of all, the one is not primordial, but itself engendered by Dao. And so it symbolizes everything that appears, is manifest - but which always presupposes the non-apparent, the non-manifest. Second, the one is conceived as full of potentialities: it does not externally create the many, but has the many in itself in an interpenetrating fashion (cf. also below, section "Energy ( $q$ 氣) and the Intensities"). Or, better, "one", "two", "three" and "myriad things" in Laozi are all multiplicities, different phases of a multiplicity. There was no need to stress the "sameness" of the One; on the contrary, the latter was conceived of as being in a continuous transformation or change (only the fact of changing does not change). 
The actualization process of this virtual multiplicity begins with a "dark precursor"8 (see DR, 119-122). The latter puts into communication two series of differences, two series that are incompatible, incongruous. It is the "differenciator of differences". It is the reverse of an identity or communality (hence the designation "dark"). And like the stepped leader is followed by a visible lightning, so also the ensuing individuation covers up the dark precursor; the differenciator of differences is buried under similarities and identities, and under the extensive quantities and qualities.

The actualization takes place on a field of individuation. Just as Bergson's memory cones together form a giant memory of the universe (at least in Deleuze's interpretation; see, for instance, Deleuze 1991, 100), so also all things and events share the virtuality, but every one of them actualizes only a small portion of it, which it takes as its field of clarity, while the rest is left in obscurity. So, for example, my field of individuation as a human being involves things of a certain scale (usually from millimetres to meters and perhaps some kilometres, from milliseconds to a couple of decades), certain types of objects (that notably include cultural artefacts), etc. Some events in the world might be in very close relation to myself, for example the metabolism in the billions of cells of my body, but they nevertheless form only an obscure background to my existence, an indistinct white noise from which occasionally some clear voices emerge, such as when a sufficient number of cells express their need for nutrients and I experience hunger. The same applies to the "outer" experience. For example, the clear perception of the sound of the sea involves an infinite number of "small perceptions", the sounds of all the different particles of water which I am normally unable to hear distinctly. It can be said generally that every perception is a contraction of smaller events, like also each body itself is a contraction of certain physiological and biochemical events, and those contractions are made in terms of the field of individuation involved.

What is distributed in a field of individuation are intensities, spatio-temporal dynamisms that unfold the virtual relations. The differences in the case of intensity are not wholly internal and reciprocal as in virtuality, but not yet wholly externalized either, so that its terms still interpenetrate each other. We can take as an example the experience of duration or spatial perception mentioned above. In my perceptual field I certainly distinguish parts as external to each other, but I cannot

8 Deleuze takes the notion of "dark precursor" from thunder research. In English the corresponding scientific term would be "stepped leader" ("dark precursor" is a literal translation of the French term précurseur sombre, and this literal translation is used in the English translation of Difference and Repetition). Before the visible lightning strikes, there is an invisible stream of ions from the cloud to the earth, and when it reaches the ground, the visible lightning occurs, following the path drawn beforehand by the stepped leader. 
dissect my perceptual experience in the manner I can dissect a thing. The same applies in the case of my duration: it has elements in a relation of before and after, but my whole past experience inheres in every part in such a way that I cannot dissect parts out of it. Or to put it more correctly, in a certain way I can divide my perception and memory, in the sense of taking a closer look, zooming in, but then, by this very act, the whole changes; "no part exists prior to the division and no part retains the same nature after division" (DR, 237), its "metric varies with division" (DR, 238).

Finally, the actual is formed by fully unfolding or explicating the intensities to form extensive quantities and qualities. This process can, by imagination, be extrapolated so that we may conceive of a pure spatiotemporal juxtaposition (complete externality of spaces and moments) whose parts are completely homogeneous, so that division (or duration) is completely indifferent to them. And this step has indeed been taken often in the Western metaphysical tradition, where space is conceived of as a contiguity of parts and time a succession of moments. But real systems always contain some heterogeneity of elements, and the intensities are never completely cancelled out under extensive parts and qualities.

Those different levels are simultaneous; each thing has, as Deleuze says, a "virtual half" and an "actual half", and the individuation takes place in-between. This, of course, is not only a question of creating differences, but also of unmaking them; there also occurs a destruction and metamorphosis of actual structures. An attitude of counter-actualization is even an important existential technique. But I shall not discuss this topic in the present paper. ${ }^{9}$

\section{Background in Chinese Tradition: Genesis by Differentiation}

Genesis-by-differentiation is deeply ingrained in Chinese philosophy. The paradigmatic passage is $\S 42$ of Laozi: "Dao begets one, one begets two, two beget three, three beget the myriad things (道生一, 一生二, 二生三，三生萬物).” Compare this to another Daoist classic, Zhuangzi, describing the genesis of a human being: "Mingled together in the amorphous, something altered, and there was the energy; by alteration in the energy there was the shape, by alteration of the shape there was the life (雜乎芒芴之間, 變而有氣, 氣變而有形, 形變 而有生)" (Graham 1981, 124). There is the understanding that (1) the genesis proceeds by differentiation, (2) the actualized products do not resemble those interpenetrating phases they are differentiated from.

$9 \quad$ I have done so in another paper, see Ott 2019. 
This seems close enough to some pre-Socratic philosophers who also describe genesis by differentiation, and specifically, as in the case of Empedocles, through two opposing forces like Love and Strife (cf. the Chinese polarity of yin-yang). Later, this idea was changed with the introduction of a Demiurge in Plato's Timaeus and the Christian God, which introduce the notion of entities transcending the process involved and superior to it. Deleuze does away with this supplementary dimension, and his account of actualization by differentiation is closer to traditional Chinese accounts of genetic processes. ${ }^{10}$

The following application of Deleuze to Zhu Xi is thus rather "safe" in the sense that both speak of the same thing. My main goal is to show that the particulars of the respective descriptions can also be fruitfully made to bear on one another.

\section{Articulation and Energy}

Zhu Xi developed a philosophy of $l i$ 理 and $q i$ 氣. Before looking more closely at Zhu Xi's texts, however, let us consider the two terms themselves.

In his translation of Zhang Dainian's Key Concepts of Chinese Philosophy (2002), Edmund Ryden provides the following account:

The term $l i$ originally meant the lines running through a piece of jade. It came to prominence as a philosophical term during the Warring States period. It is then often translated as "pattern". By the Song dynasty it rose to become the most important metaphysical concept and hence is generally translated as "principle". (Zhang 2002, 26-27)

In what follows, I would like to keep the older meaning present while interpreting Zhu Xi: $l i$ as the veins in a jade or (an example more familiar to Westerners) in marble. ${ }^{11}$ Philosophically, it denotes the articulations of a thing or an event.

10 It may also be noted that whereas some of the most dominant metaphors in the West come from pottery and herding, the most dominant metaphors in China come from gardening or grain cultivation, from seeds and plants (see Munro 2015, 130-32; Zhang 2002, 83). This also favours thinking in terms of differentiation, as we can observe the latter in the development of a seed into a plant (while the maturation of the foetus of a mammal is more hidden). On the other hand, pottery seems to fit a hylomorphic way of thinking: how to implement a form or an idea to a relatively homogeneous mass.

11 In searching for alternatives for "principle" one could also consider other words, like "pattern" or "structure". But I would like to reserve the first term for translating wen 文 in the old texts, and the latter has connotations of rigidity or abstractness that are both alien to Zhu Xi's thought. Instead, veins are flexible and are naturally meant for something to flow in them. 
The second concept, $q i$, is explained by Edmund Ryden as follows:

Perhaps the best translation of the Chinese word $q i$ is provided by Einstein's equation $\mathrm{E}=\mathrm{mc}^{2}$. According to this equation matter and energy are convertible. (...) $Q i$ embraces both. (...) In popular parlance $q i$ is applied to the air we breathe, steam, smoke, and all gaseous substances. The philosophical use of the term underlines the movement of $q i$. (...) $Q i$ is the life principle but is also the stuff of inanimate objects. As a philosophical category $q i$ is originally referred to the existence of whatever is of a nature to change. (...) It is energy that has the capacity to become material objects. (Zhang 2002, 45-46).

$Q i$ is often left untranslated or sometimes translated as "life-breath", but as Ryden explains, it is not limited to animate beings. Wing-tsit Chan translates it as "material force" (Chan 1963, 784), which is a rather strange rendition (are there any other forces than material? what matter would correspond to the yin qi 陰氣 or yang qi 陽氣?). In what follows, I shall translate it simply as “energy", although it should not be equated with the energy in the physical sense.

It is easy to understand how an ontology can be made around the concepts of veins and energy, because every phenomenon has a certain articulation and a certain energy or movement, and it can be applied both to physical and psychological phenomena. A proton is made up of three quarks, that is, has the articulation of two up-quarks and one down-quark. It also has an energy (that is partially expressed by its mass). Or psychologically: an idea, memory, yearning, etc., all have an articulation and also an inherent striving, movement or conatus, that drives them to the next moment, and then to the next, thus securing their duration.

It can also be argued that an energy without articulation could not manifest itself in any way, because all appearing requires that the appearing something must have an inner articulation that also makes it distinct from the rest (the inner differences of an entity and the difference of the entity itself from the outside are strictly simultaneous, with one presupposing the other). On the other hand, an articulation without energy is also inconceivable: because epistemologically speaking even a most abstract structure presupposes a subject that is holding it in her mind, and this holding is a temporal process that implies a certain energy, striving, conatus, etc. Speaking ontologically: an articulation that is not connected to any energy remains a pure virtuality without any actuality. 


\section{Zhu Xi and the Veins}

By making a connection between Deleuze's virtuality and Zhu Xi's concept of the veins, I do not mean to say that they are the same, but rather that the concept of the veins could be fruitfully interpreted in Deleuzian terms. There are some considerations that warrant such interpretation.

First, the notion of the veins appears in the context of an account of differentiation. As said above, differentiation is the mainstream ontology in the Chinese tradition, probably first developed in the Daoist context and later accepted by Confucianism and, to some extent, even by Buddhism. The veins play a key role in explaining differentiation, as does the virtual in Deleuze. Zhu Xi explicitly says that the differentiations of the veins are different (其分不同) (Yulei 6, 5b; QS 14, 237 12 ).

Second, the veins are called “minute" wei 微 ("the most minute is called the veins" 至微者理也); this is reminiscent of the Deleuzian virtual which is said to be made of differential relations that are infinitely small. Incidentally, "differential relation" in modern Chinese is translated as weifen guanxi 微分關係, with the same word wei as for "minute". Of course, differential calculus did not exist in the 12th century China, but there is an idea of invisible minute differences that through unfolding become macroscopic and visible. This idea can be extrapolated or abstracted even by a naive mind while observing the development of a seed, where in the beginning it is hard or impossible to apprehend any differences with the naked eye, but because we know that distinctions are developed from it, we can infer that there must have been former invisible minute differences in the seed. ${ }^{13}$

Third, the veins are immanent. Like the energy (which is related to the intensities, as discussed below) they "depend on each other and never separate from each other (常相依而未嘗相離也)” (Yulei 94, 19b; QS 17, 3128-29), “in the world there is no energy without veins, and no veins without energy ${ }^{14}$ (天下未有無理之 氣，亦未有無氣之理。氣以成形，而理亦賦焉)" (Yulei 1, 2b; QS 14, 114). It is also immanent both to the "images" (xiang 象, which denotes an intermediary level of actualization): "inside the images there are the veins, and there is no

12 Two references are given for Zhu Xi citations: (1) from the traditional Qing dynasty Siku quanshu edition, with the number of the chapter and page (a or b side), (2) from Zhuzi quanshu (Zhu 2002, abbreviated as QS), with the number of the volume and page.

13 Deleuze also relies heavily on embryology in his description of differentiation (DR, 214-19, 237$38,249-51)$.

14 The translations from the first juan of Zhuzi yulei are from Patrick Edwin Moran's draft translation (Zhu 2003), but have been modified somewhat. 
distance between them (象中有理, 是無間也)” (Wenji 40, 41b; QS 22, 1841) and to the "things" ( $w u$ 物, which denotes the level of the actual): "there is nothing that does not have these veins (莫不各具此理)” (Yulei 18, 15b; QS 14, 606).

There is, though, a properly Chinese distinction of "above the forms" (形而上) and "among the forms" (形而下). ${ }^{15}$ The veins are said to belong to the former (“the veins are above the forms (理形而上者)" (Yulei 1, 3b; QS 14, 115)), while actual things and events (shiwu 事物) belong to the latter ("form" here designates all actual things with a form and can be taken more or less simply as a synonym for "thing"). But it would be very misleading to take the "above the forms" in the sense of a Platonic realm of ideas that transcends the sensible things. ${ }^{16}$ Both are invisible (“the veins cannot be seen (理不可見)” (Yulei 94, 17a; QS 17, 3126)), but the Platonic invisible forms belong to a completely different realm than the sensible and they can only be apperceived with the eye of the mind or reason, whereas the invisible veins in Neo-Confucianism still very much belong to our world. So, the "above" in both cases implies a completely different metaphor: the Platonic ideas are "above" as reason is above the body and the gods are above the humans, while the Neo-Confucian "above" refers to small streams flowing here and there in the hills, and only when they move downward do they acquire a more definite form of a river. Philosophically, they denote the "upstream" and "downstream" levels of a process of actualization. ${ }^{17}$

One of the main obstacles in this comparison is that Zhu Xi refers to the veins as "one": "the veins are one ${ }^{18}$ (liyi 理一)" (Yulei 1, 2b; QS 14, 114); it is the first part of the famous phrase "The veins are one and its differentiations are many (liyi fenshu 理一分殊)". What are we to make of this? According to Deleuze's distinction, we could interpret the "one" of the veins as completeness, not as wholeness: the virtual is complete, but not whole. In the virtual, there is the reciprocal

15 The term originates from the Xici 繫辭 (Appended Statements) commentary to the Book of Changes. The Xici commentary or The Great Commentary (which is not a systematic commentary, but an independent text compiled from different sources) was composed between the 4th and 2nd centuries BC. It was later considered as an integral part of the Book of Changes, making up two of its "Ten Wings". The Xici commentary is the most philosophical part of the Book of Changes, and when a philosopher cites the Book of Changes, very often the source is the Xici.

16 Incidentally, the Western term for "metaphysics" has been translated into Chinese as "the study of the above-the-forms" (形而上學), which is quite misleading (or which involves an important reinterpretation of the term).

17 François Jullien uses the French terms en amont ("upstream") and en aval (“downstream") to explain this Chinese conception and employs them as concepts (Jullien 2004, 42, 116 et passim). It should also be noted that Jullien has done pervasive work with Deleuzian inspiration with different aspects of Chinese tradition (although he rather seldom acknowledges the loans or the similarity).

18 There is no grammatical number in Chinese, so the choice of singular or plural in the translation is often arbitrary. 
co-determination of differential relations and the complete determination of how singular points are distributed; however, the virtual is just one part of the object, the other part being its actualization (see DR, 46-47, 208-11). In Zhu Xi the movement of the energy depends on the structure of the veins: "If yin and yang, and five phases intertwine, without losing their sequence, this is the veins (如陰 陽五行錯綜不失條緒, 便是理)" (Yulei 1, 4b; QS 14, 116). So, the complementarity of the different modes of energy (yin and yang, five phases) could be seen as based on the reciprocal determination in the veins and also on the complete determination of singular points that are folded out in the intensive processes of actualization of the energy.

\section{Status of the Veins}

The relation between the veins and other phases of actualization (first of all, energy), already puzzled Zhu Xi's own students, who asked their master about it several times, and it has remained a topic of scholarly debate ever since. To begin with, Zhu Xi strongly affirms that they are inseparable: "In the world there is no energy without veins, and also no veins without energy (天下未有無理之氣， 亦未有無氣之理)" (Yulei 1, 2b; QS 14, 114), “the veins are never separated from the energy (理未嘗離乎氣)” (Yulei 1, 3b; QS 14, 115). But on the other hand, he accords priority to the veins ${ }^{19}$ : “the veins are before (先有理)" (Yulei 1, 2a; QS 14, 114 and elsewhere); "when there are veins there is immediately also the energy, but the veins are the root (有是理便有是氣, 但理是本)" (Yulei 1, 2b; QS 14, 114); "In the final analysis, before there was either heaven or earth there were first these veins (未有天地之先, 畢竟是先有此理)” (Yulei 1, 1a; QS 14, 113). Still, it should not be considered as a temporal priority: "you cannot say that today there are such-and-such veins and tomorrow there is such-and-such an energy (不可說是今日有是理, 明日卻有是氣)” (Yulei 1, 5a; QS 14, 116). The veins “are not separate, yet do not mix” (buli buza 不離不雜, as says Qing dynasty scholar Lu Longqi 陸隴其, 1630-1692 20 ): they are ontologically distinct, but not separable.

However, when we try to look more closely into their relation, we are met with difficulties. There are passages where Zhu Xi seems to affirm that "the veins produce the energy (理生氣 ${ }^{21}$ )" or that “the energy is produced by the veins $($ 氣 $(\cdots)$

19 There are other ontologies that stress the priority of the energy, for example Zhang Zai 張載 (1020-1077), Wang Tingxiang 王廷相 (1474-1549), Wang Fuzhi 王夫之 (1619-1692).

20 See https://www.kanripo.org/text/KR4f0040/001\#1a (1.6b).

21 See https://www.kanripo.org/text/KR5i0079/001\#txt (1.6a). 
是理之所生)" (Yulei 4, 26a; QS 14, 200), thus making the veins prior in a stronger causal sense. In this case the veins (as equivalent to Deleuze's virtual) would initiate the activity of differenciation. ${ }^{22}$ But taking into account certain factors (rarity of appearance, lesser authoritativeness of the texts, the general framework of his philosophy), scholars usually tend to think that it doesn't refer to production in a chronological or causal sense, but rather means the actualization "according to" the veins, in the sense that the energy unfolds the "minute" and "above-theforms" differences of the veins (see, for instance, Yang 2015; Chen 2016). In yet another passage, Zhu Xi says that "the veins are above yin and yang like a man riding a horse (理搭在陰陽上, 如人跨馬相似)” (Yulei 94, 17; QS 17, 3126), which according to the metaphor would imply that the veins have directive power over the energy.

Still, in another and more developed text, Zhu Xi says that the veins are "without any will or intent, without any ability to plan, without the ability to bring anything into existence (無情意, 無計度, 無造作)” (Yulei 1, 5a; QS 14, 116); are only “a sterile and empty world that does not contain a single trace (則只是箇淨潔空 闊底世界，無形跡)" (ibid.); (“trace” in the sense of something detectible, already actualized). According to this, the veins by themselves do nothing. Zhu Xi explains that it is the energy that gives a "place" to the veins, an anchoring point, so to say. "Yet the veins are not a separate entity. They exist amid the energy. If there were not this energy, then the veins would have no place to which to hook or from which to hang (然理 又非別為一物, 即存乎是氣之中: 無是氣, 則是 理亦無掛搭處)” (Yulei 4a; QS 14, 115); “when energy does not consolidate, then the veins have no place in which to inhere (若氣不結聚時, 理亦無所附著)” (Yulei 4b; QS 14, 116).

There is a similar scholarly debate about the relation of the virtual and intensive in Deleuze: which of them should be considered as the preferred ontological level? Some would stress the virtuality (Badiou 1999, 43-54; Ansell-Pearson 2002, 99, 111; Hallward 2006, 28) and see it as the source of activity; others stress the intensities (Hughes 2009, 142; Bowden 2017, 236; Lundy 2017, 183) and say that the virtual is just a structure that by itself does nothing. The quotes from Zhu Xi's in the previous paragraph are closer to the latter interpretation; however, the passages in which the veins are said to produce the energy could be taken to support the former interpretation.

It might be useful to distinguish between priority by initiation and priority by beginning. The intensities are what initiate actualization because they are the first

22 Deleuze distinguishes between "differentiation" in the virtual itself and its "differenciation" of the virtual into actual forms (DR, 207). 
stages of it. But this actualization unfolds virtual differential relations and singular points, which are the beginning of an actualization. In Deleuze's words: "The nucleus and the genes designate only the differentiated matter - in other words, the differential relations which constitute the pre-individual field to be actualised; but their actualisation is determined only by the cytoplasm, with its gradients and its fields of individuation" (DR, 251). So, the actualization of a cell begins from the DNA, but is initiated by the cytoplasm.

\section{Dark Precursor and the Supreme Ultimate}

In Deleuze, the very beginning of actualization is with the dark precursor that brings together different orders of differences and makes them resonate. In Zhu $\mathrm{Xi}$ a somewhat similar role is played by the supreme ultimate (taiji 太極). The term was made famous by the Xici 繫辭 commentary of the Book of Changes:

In change there is supreme ultimate, which generates the two modes. The two modes generate the four images, and the four images generate the eight trigrams. (Adler 2015, 39, translation modified)

易有太極，是生兩儀，兩儀生四象，四象生八卦。

The term became popular in Daoist circles and was introduced into the Song dynasty's Neo-Confucian philosophy by Zhou Dunyi's 周敦頣 short text the Explanation of the Diagram of the Supreme Ultimate (Taijitu shuo 太極圖說) that opens as follows:

Without ultimate and yet the supreme ultimate! The supreme ultimate through movement generates yang. When its activity reaches its limit, it becomes tranquil. Through tranquillity the supreme ultimate generates yin. When tranquillity reaches its limit, activity begins again. So, movement and tranquillity alternate and become the root of each other, giving rise to the distinction of yin and yang, and the two modes are thus established. (Chan 1963, 463, translation modified)

無極而太極。太極動而生陽, 動極而靜, 靜而生陰, 靜極複動。 一動一靜, 互為其根。23

23 The Chinese original is available at the Chinese text project, see http://ctext.org/wiki.pl?if=gb\&chapter $=942058$. 
In both cases the supreme ultimate appears in the context of a cosmological and ontological account of differentiation, at the very outset of actualization, in the position before the differentiation of the energies of yin and yang. As Zhu Xi says: "Supreme ultimate's cleavage is just yin and yang, and it comprises all the things under heaven (太極分開只是兩個陰陽, 括盡了天下物事)” (Yulei 94, 1a; QS 17, 3115).

There is some ambiguity in Zhu Xi. On the one hand, he equates the supreme ultimate with the veins: "The supreme ultimate is just the veins of heaven, earth, and the myriad creatures (太極只是天地萬物之理)" (Yulei 1, 1a; QS 14, 113) and even more bluntly, “The supreme ultimate is just the word 'veins' (太極只是 一箇「理」字)” (Yulei 1, 2a; QS 14, 114).

The supreme ultimate is just the veins of heaven, earth, and the myriad things. Speaking with regard to heaven and earth, then within them there is the supreme ultimate. Speaking with regard to the myriad things, then within them there is the supreme ultimate in each of them. Before there was heaven or earth there must have been first the veins. In moving it produces yang, and this is also veins. In being still it produces yin, and this is also veins.

太極只是天地萬物之理。在天地言, 則天地中有太極; 在萬物 言, 則萬物中各有太極。未有天地之先, 畢竟是先有此理。動而 生陽, 亦只是理; 靜而生陰, 亦只是理。(Yulei 1, 1ab; QS 14, 113)

But in another place, there is a dictum, where Zhu Xi says that the supreme ultimate is energy: ${ }^{24}$

Ten thousand things, four seasons and five phases come just from the supreme ultimate. The supreme ultimate is just one energy. By proceeding it differentiates itself and makes the two energies. Among them the moving (energy) is yang and the quiescent (energy) is yin. By again differentiating, it creates the five energies and then scattering it becomes the ten thousand things.

24 In the Qing dynasty edition of Master Zhu's Complete Works (1714) this citation (49.9b) was placed immediately after the previous one, although it certainly comes from a different time and context. Master Zhu's Complete Works actually was not the complete works and it should not be confused with the modern edition of complete works that I am usually referring to in this paper. I shall refer to this old edition as Quanshu. The electronic version of the chapter is available at https://www.kanripo.org/ed/KR3a0108/WYG/049. 
萬物四時五行只是從那太極中來。太極只是一個氣，迤麓分做兩 個氣。裏面動底是陽, 靜底是陰, 又分做五氣又散為萬物。(Yulei 3, 14a; QS 14, 163)

Although there are many citations supporting the idea that the supreme ultimate belongs to the veins, it is clear that it cannot be simply identified with them, because the supreme ultimate is creating, generating, "moving". Explaining Zhou Dunyi, Zhu Xi says:

"By moving it begets yang and by being still it begets yin". "Moving" is the supreme ultimate's moving and "being still" is the supreme ultimate's being still. When it moves, it then begets yang and when it is still, it then begets yin, it produces the energy of this yin-yang.

“動而生陽, 靜而生陰”, 動即太極之動, 靜即太極之靜。動而後生 陽, 靜而後生陰, 生此陰陽之氣. (Yulei 94, 4a; QS 94, 3118)

But no such movement can be attributed to the veins. Zhu Xi accepts Zhou Dunyi's interpretation that the supreme ultimate generates yin and yang. It constitutes the very first distinctions: "If there were no taiji, then heaven and earth would not fold themselves out (若無太極，便不翻了天地！)”(Yulei 1, 2a; QS 14, 114).

So, we might conclude that the supreme ultimate is close to the veins, but already one step towards actualization. Let us now take a closer look at the metaphor involved. The term taiji is composed of two parts: tai 太 "very big", "great", "supreme" (more emphatical than simply $d a$ 大 "big") and $j i$ 極, which usual meaning is “extreme", “very”, “utmost”. Rao Lu 饒魯, a student of Zhu Xi's principal student, explains the term as follows:

The term taiji expresses the majesty of the universal pattern (tianli 天理, "heavenly veins"). The word $j i$ means axis or pivot (shu 樞), knot or node (niu 紐), root (gen 根), or basis (di 柢); as we say in common speech, shuji 樞極 (axis), or genji 根極 (root). (...) The word tai 太 means so great that nothing can be added, and expresses the fact that it is the Great Pivot and the Great Basis of the universe. All things, however, which bear this name, such as the North (celestial) Pole, the South (celestial) Pole, the ridge of a house (wuji 屋極), the Capital of Shang, or the four compass-point directions, have visible forms and locations to which we can point, but this $j i$ alone is without form, and has no relation to space. Master Zhou therefore added the term wu 無 (wuji 無極), expressing the fact that it is not (confined to) any form such as that of a nodal pivot or a 
basic root, yet nonetheless is really the Great Nodal Pivot and the Great Basic Root of the universe. (Needham 1956, 465, slightly modified)

所謂太極者，蓋天理之尊號云爾。極者，至極之義，樞、紐、 根、柢之名，世之常言所謂樞極、根極是也。(...)太者，大無以 加之稱，言其爲天下之大樞紐、大根柢也。然凡謂之極者，如南 極、北極、屋極、商邑、四方之極之類，皆有形狀之可見，方所 之可指。而此極獨無形狀之方所, 故周子復加無極二字以明之。 以其無樞紐、根柢之形，而實爲天下之大樞紐、大根柢(...)。25

According to these different metaphors, taiji is the highest tip (like a ridgepole), the deepest or furthest point (tip of a root), the innermost centre (pivot) of every single thing, and also of the universe as a whole. It is the incipient stage or point of a thing, a quasi-nothingness. Indeed, according to a classical Chinese saying from the Laozi, the wheel is understood to rotate around a nothingness: "Thirty spokes join one hub. The wheel's use comes from emptiness (三十輻, 共一瑴, 當其 無, 有車之用)” (Lao-Tzu 1993，15). Although the focus of Laozi's dictum is elsewhere (that you need a hole in the middle of the wheel where to put the axle and thus to make the wheel "usable"), it was also understood more generally that the centre or pivot of the very being is a "nothingness". Of course, Daoism is something Zhu Xi wants to clearly distance himself from (and therefore also he downgrades the importance of the notion of wuji $i^{26}$ "without ultimate"), but this background of the notion of the supreme ultimate might serve our purpose here to make a connection with Deleuze's dark precursor, because both refer to the very beginning of individuation. In this sense we might agree with everything Joseph Adler (2015) says in his thorough discussion on the translation of taiji - that it is a generating point of a thing/event ${ }^{27}$ and that things and events always manifest themselves in polarities (two ends of a thing, ${ }^{28}$ two phases - yin and yang - of a process) - with the exception of Adler's conclusion that, for that reason, taiji should be translated as "Supreme Polarity". What engenders polarity is itself not polar; every polarity belongs already to the sphere of the energy, intensities. Taiji is not a polarity (even a supreme one), but rather the negative of a polarity (in

25 The Chinese original is available at https://www.kanripo.org/text/KR3a0078/001\#1a (1.19ab).

26 According to Zhu Xi, Zhou Dunyi simply wants to stress with this term that the supreme ultimate is not a thing. But historically it seems more plausible that the wuji referred to a level of existence before taiji, perhaps some kind of primordial chaos.

27 "Like a pivot point, it is dimensionless yet constitutes the central axis of change and differentiation." (Adler 2015, 62)

28 Indeed, the common word for "thing" in contemporary Mandarin is dongxi 東西 that literally means "east-west", referring to the polar constitution of everything. 
the photographic sense of the "negative"), like Deleuze's invisible dark precursor which draws "in the negative" the path that the visible lightning will take.

This would enable us to finally surpass the fruitless aporias of the one and the many that are present both in Zhu Xi himself and his interpreters, right up until today. ${ }^{29}$ It would be better not to consider the supreme ultimate as a somehow condensed duality or polarity, because this would mean that its two parts already belong together and have some similarity, thus imposing on it the fourfold yoke of representation (DR, 34, 264), subjecting the difference to the identity of the relation and the similarity of its parts. It would be better to consider the supreme ultimate as a dark precursor, a non-thing that brings together two different sets of differences, or, to put it in different linguistic terms, the place where two different sets of differences come together and enter into resonance, forming a system that will maintain in itself this paradoxical instance of the dark precursor that serves as the generating point of the system.

\section{Field of Individuation and the Supreme Ultimate}

There is another aspect of the supreme ultimate that draws it nearer to another one of Deleuze's notions, namely the field of individuation. Zhu Xi distinguishes between two modes of the supreme ultimate that are called weifa 未發 and yifa 已發. $F a$ 發 literally means "send forth", “emit", "release", "shoot” (e.g. an arrow), "express", "open", "expose". The two expressions thus mean, respectively, "not yet emitted (expressed, exposed, etc.)" and "already emitted". The first aspect is closer to the veins or the virtual, the latter to the intensities. According to another common Chinese metaphor that sees quiescence, tranquillity or stillness as more primordial than movement, Zhu Xi also relates weifa to stillness and yifa to activity: "Not-yet expressed is taiji's stillness and already-expressed is taiji's movement (未發者太極之靜,已發者太極之動)” (Quanshu 49, 19b). The actualization is seen as a movement from the not-expressed to the expressed: it "flows and moves in the phase of the already-expressed and is held in reserve at the occasion of the not-yet expressed (流行於已發之際, 斂藏於未發之時)”(Quanshu 49, 13b).

29 "Zhu Xi understood taiji to be the most fundamental cosmic ordering principle, which is, to be specific, the principle of yin-yang polarity. In other words, the simplest, most basic ordering principle in the Chinese cosmos is the differentiation of unity into bipolarity (not duality). Wuji er taiji (無極而太極, 'without ultimate and yet supreme ultimate'), then, means that this most fundamental principle, bipolarity - despite its evident 'twoness' and its role as the ultimate source of multiplicity - is itself, as a rational ordering principle, essentially undifferentiated." (Adler 2015, 68) It does not help if "duality" is simply replaced by "bipolarity". It is not possible to generate a universe from "one" or from the "undifferentiated", but only from a virtual multiplicity. 
So, while the supreme ultimate's state of not-yet-expressed or emitted might be related to Deleuze's dark precursor (which is exactly the point of starting to emit, express, resonate, individuate), the supreme ultimate's state of already-expressed might be related to Deleuze's field of individuation. If according to one aspect of the metaphor of the supreme ultimate or extreme it can be seen as the genetic starting point of an individual and as the dark precursor, then according to another aspect of the same metaphor it can be seen, by synecdoche of pars pro toto, a part standing for the whole of the thing, as the condensation or concentration of an individual. As Chen Chun 陳淳 (1159-1223) says:

The greatest extent of anything is always in its centre. Things from all directions reach their ultimate point here and cannot go any further. Take the ridgepole of a roof. It is called the wuji (屋極) (terminus of a building). It is simply the converging point of all building materials from the various directions, reaching their terminus at this centre. (Chen 1986, 117)

蓋極之為物，常在物之中，四面到此都極至，都去不得。如屋脊 梁謂之屋極者，亦只是屋之眾材，四面湊合到此處皆極其中。30

There is something of a "converging point" also in Deleuze's notion of the field of individuation. In that part of his ontology he relies heavily on Leibniz, who describes individuals in terms of viewpoints:

Just as the same city viewed from different sides appears to be different and to be, as it were, multiplied in perspectives, so the infinite multitude of simple substances, which seem to be so many different universes, are nevertheless only the perspectives of a single universe according to the different points of view of each monad. (Leibniz 1989, Monadology $\S 57,648)$

Although the metaphor is not the same (more "physical" in $\mathrm{Zhu} \mathrm{Xi}$, and more "epistemological" in Leibniz), they share an order of implication of differences or distinctions: in Chen's citation, the ridgepole implies all its materials, while Leibniz' viewpoint of a monad implies the sensible multiplicity of a city, brought together in a "metaphysical point" and made to interpenetrate there.

What is more, the different fields of individuation in Deleuze/Leibniz, as well as the supreme ultimates of every being/event in $\mathrm{Zhu} \mathrm{Xi}$, involve all the other beings and the whole world. Only a portion of the virtual relations is expressed clearly in a field of individuation; the rest remains implied in obscurity. Zhu Xi says:

30 The Chinese original is available at https://www.kanripo.org/text/KR3a0107/010\#1a (10.3a). 
Fundamentally there is only one supreme ultimate, yet each of the myriad things has been endowed with it and each in itself possesses the supreme ultimate in its entirety. This is similar to the fact that there is only one moon in the sky but when its light is scattered upon rivers and lakes, it can be seen everywhere. It cannot be said that the moon has been split. (Chan 1963, 638, translation slightly modified)

本只是一太極, 而萬物各有稟受,又自各全具一太極爾。如月在 天，只一而已，及散在江湖，則隨處而見，不可謂月分也。(Yulei 94, 71ab; QS 17, 3167-68)

So, all the supreme ultimates imply or involve each other. Supreme ultimates are immanent to each individual, they imply each other and remain differentiated:

The ten thousand things differentiate the reality of the one vein system and take it as their rhizome-body $(t i \text { 體 })^{31}$ and therefore among the ten thousand things, every one has a supreme ultimate, but small and big things all have a certain distinction.

一理之實，而萬物分之以為體，故萬物之中，各有一太極，而小 大之物，莫不各有一定之分也。(Yulei 94, 71a; QS 17, 3167)

This way of individuation by differentiation ${ }^{32}$ makes it possible to overcome the traditional Western analysis by genus, species and individuals that still hampers

$31 T i$ 體 is one of the key concepts of Chinese philosophy (see Gedalecia 1974). It forms a pair with yong 用, “function", "application", "use", and refers to the "above the forms", while function is "among the forms". Ti has been translated as "essence" or "substance", but these Western concepts, with a long history and strong connotations, are rather misleading here (in Wang Yangming, Iso Kern tries to distinguish $t i$ according to these two notions, i.e., Wesen and Substanz, but I do not find his analysis particularly convincing, see Kern 2010, 189-94), because it does not form a pair with the inessential or accidental but is formed on the basis of the logic of differentiation, as the virtual level of things and events. Etymologically $t i$ means "body", and Deborah Sommer (2008), who has analysed different Chinese notions of the body, has pointed out that the $t i$-body is a kind of rhizomatic body. Of course, Zhu Xi does not here refer to any notion of Deleuze's rhizome, and in other places uses traditional tree metaphors. But even in the tree metaphor, the emphasis lies elsewhere: while in the West, it has been mostly used to stress the hierarchic relationship - some things are more basic than the others, like the trunk and the branches - in China the emphasis lies rather on the differentiation - the trunk differentiates itself into branches and branches into leaves (in a "upstream" and "downstream" relation), and if the roots have a certain priority, it is because they come before in the order of differentiation.

32 See also Quanshu (49, 16a): "The supreme ultimate is like the root that produces what is above, differentiates itself into the trunk and branches, and then again produces flowers and leaves, producing and reproducing (shengsheng 生生) without exhausting (太極如一本生上, 分為枝幹, 又分而生花生葉, 生生不窮).” 
interpreters. ${ }^{33}$ The beings thus actualized are not subject to any requirement of identity in the concept or similarity in realization. It would be better not to see the "one" of the veins or of the supreme ultimate as a reference to identity, but to (re) interpret it as a virtual multiplicity that unfolds into actual beings.

\section{Energy ( $q i$ 氣) and the Intensities}

Energy stands for the next step in the process of actualization. It belongs to the realm of "among the forms (形而下)" (Yulei 1, 4a; QS 14, 115); it is "coarse" ( $c u$ 粗) and contains sediments, dregs or residue ( $z h a z i$ 渣漳) (ibid.). This means that it is capable of accumulating ( $j i$ 積) and coagulating or condensing (ningju 凝聚) into matter or stuff ( $z h i$ 質). ${ }^{34}$ It is this coagulation or condensation that gives veins a "place" (chu 處), as we mentioned when discussing them; that is, an anchoring point, so that energy can be channelled into its different branches, specific to every being and event. Without this anchoring point, the veins would remain ineffective; it is energy that gives them the capacity to actualize, and once in contact with the energy, the veins direct their actualization process. Zhu Xi compares the situation to a seed:

It is just in this way that in the entire world in the case of humans, creatures, vegetation, and beasts, there are none that are born without a seed. There is certainly no possibility of a thing or an event being born on a featureless plane from no seed whatsoever. All of this is energy. In the case of the veins there is only a clean and pure, empty and broad world without forms and traces. It cannot produce anything. But energy can ferment, coagulate, and bring forth things. But if there is this energy, there are the veins to be found within it.

33 For instance, it distorts Kirill Thompson's otherwise very insightful description of Zhu Xi, when he says: " $Q i$ bodies forth an object's presence and yields specificities of its peculiar tangible traits; $l i$ is relatively implicit for it gives the inherent patterning that yields the kind of object and its range of typical responses and interactions. Qi gives the particular stuff of the object and thus its distinctness and uniqueness vis-à-vis other things of the same kind" (Thompson 2015, 153). Here, it seems as if the veins give the specific form to a being, while the energy differentiates between individuals, just as matter has often been held responsible for the individual differences within the same species. This kind of analysis still moves under the fourfold yoke of representation, under the presupposition of the identity within the concept (here, species), and similarity in the physical expression (individuals).

34 "First there are heavenly veins and yet there is also energy. Energy accumulates and becomes stuff, and the nature is concretely present therein (先有箇天理了, 卻有氣。氣積為質, 而性具焉)” (Yulei 1, 2b; QS 14, 114); the term translated as "nature" xing 性 refers to the virtual aspect of a being and belongs to the sphere of the "veins"; "Energy can ferment, coagulate, and bring forth things (氣則能䤄釀凝聚生物也)” (Yulei 1, 5a; QS 14, 116). 


\section{且如天地間人物草木禽獸，其生也，莫不有種，定不會無種子白 地生出一箇物事, 這箇都是氣。若理, 則只是箇淨潔空闊底世 界，無形跡，他卻不會造作; 氣則能醞釀凝聚生物也。但有此 氣，則理便在其中。(Yulei 1, 5a; QS 14, 116)}

The two most important characteristics of energy, according to $\mathrm{Zhu} \mathrm{Xi}$, are movement and transformation. The movement of energy has two basic aspects, yin and yang, or rest and movement (so that energy in a deeper sense is the movement of or alternation between rest and movement). Zhu Xi often cites the Xici commentary of the Book of Changes: "A yin and then a yang is called the Way, and what gives continuity to it is good (一陰一陽之謂道, 繼之者善也)”, where the “continuity” is “the end of rest and the beginning of movement (靜之終，動之始)” (Yulei 1, 3a; QS 14, 115). ${ }^{35}$ Continuation and alternation are two important aspects of energy: "If there were just an opening out followed by a closing in, but no continuation, then (the process) would be stifled (若只一開一閭而無繼, 便是闔殺了)” (ibid.). Movement and stillness are equiprimordial: before rest there is movement, and before movement there is rest, endlessly.

(Alternations between) movement and rest are without an end, and (alternations between) yin and yang are without a beginning; so, it is not possible to distinguish between former and later. For the moment I will address myself to the place of origination to speak of it. Before movement there is, after all, rest (...), before yang there is yin; yet before (...) rest there is movement. What should be taken as prior and what as posterior? One cannot simply say that today's movement is taken to be the beginning and neglect to mention the rest that was there yesterday. Take breathing for instance, if we say huxi (exhale-inhale) then it sounds right; we cannot say $x i h u$ (inhale-exhale). ${ }^{36}$ But before exhalation there is, after all, inhalation and before inhalation there is exhalation.

動靜無端，陰陽無始，不可分先後。今只就起處言之，畢竟動前 又是靜， [...] 陽前又是陰，而[...]靜前又是動，將何者為先後？不 可只道今日動便為始，而昨日靜更不說也。如鼻息，言呼吸則辭 順，不可道吸呼。畢竟呼前又是吸，吸前又是呼。(Yulei 1, 1b; QS $14,113-14)$

35 The idea of a differential between rest and movement is later developed by Tan Sitong (Tan 1984, chap. 15).

36 That is, the word for "respiration" in Chinese is a compound word where by convention the exhalation is mentioned first; to say it in reverse order is incorrect linguistically but would be equally correct with regards to the phenomenon referred to. 
It is also important that Zhu Xi rejects any easy identification of the veins with the "one" and energy with "many":

When we discuss the one origin of ten thousand things, then the veins is the same and the energy differs; if we look at the different rhizome-bodies of the ten thousand things, then they are close according to their energy, whereas the veins are definitely not the same. Energy can be different in its purity or admixture; the veins can be different in their partiality or wholeness.

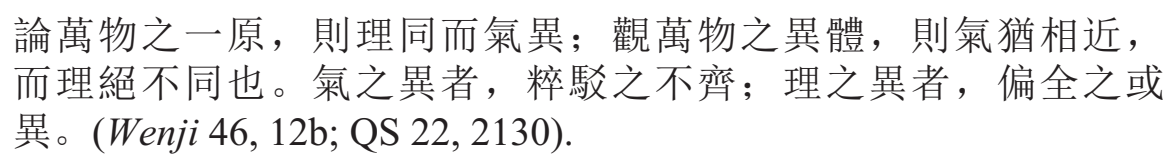

Differences in the energy and in the veins have consequences on both the moral and ethical plane: for instance, a sage's energy is purer than that of a "small person" (xiaoren 小人). This also explains man's superiority over animals: it is not a difference of nature, but of degree (in purity and wholeness). ${ }^{37}$ However, a more detailed discussion of Zhu Xi's moral psychology lies outside the scope of this paper.

Although the description of intensities by Deleuze and that of energy by Zhu Xi are certainly not identical, it still holds that both refer to the creation of spatiotemporal structures, and that during this process the mutual interpenetration of different individualizing factors decreases and spatiotemporal juxtaposition increases, so that, indeed, the beings (coagulate). Zhu Xi distinguishes a separate phase here, one that precedes the completely actualized things, namely the "five phases"38 (wuxing 五行): wood ( $m u$ 木), fire (huo 火), earth ( $t u$ 土), metal (jin 金), and water (shui 水). Usually, the term qi, or “energy", is applied both to yin-yang and to five phases, but Zhu Xi sometimes makes the distinction where he reserves the

37 The Brothers Cheng, whom Zhu Xi often cites, use the metaphor of river to explain the purity of energy or lack of it: a river is pure when it comes from the fountain, but some rivers soon become muddy, while others remain pure until they reach the sea. Zhu Xi also uses another metaphor: "The activity of production by transformation is like a grindstone wheel which rotates on and on without stopping. The production of the myriad creatures is like things being thrown off from the wheel, some things are coarse, and some things are fine, and (the process) is naturally uneven (造化之 運如磨, 上面常轉而不止. 萬物之生, 似磨中撒出, 有粗有細, 自是不齊)” (Yulei 1, 11b-12a; QS $14,121)$. While there is a normativity here, which is alien to Deleuze, the intensive processes are described as naturally different, which is a common trait with him.

38 They used to be translated as "five elements", due to some similarity to Greek four elements, but these systems are very different. The Chinese wuxing 五行 comprises the word xing 行 “to move", "to walk". And those five "movements" are seen in a dynamic relation of production and overcoming (which is why they can be seen as "phases" of a process). 
term qi only for yin-yang and terms the five phases as $z h i$ 質 “stuff”, “matter". ${ }^{39}$ In any case it is clear that they represent a further step of actualization by their greater number (five instead of two) and by their more concrete content (wood, fire, etc.; although, of course, these terms do not refer only to the empirical wood or fire, but to a certain quality of processes and things).

We could take the yin-yang as a symbol of the heterogeneity of the series of differences brought together by the dark precursor or not-yet-emitted taiji. It is easy to construe the yin-yang in terms of oppositions: submissive-dominant, cold-hot, dark-light, etc. But through Deleuze's lens we could consider these oppositions as the covering over of a deeper disparity. Those opposites or complementary aspects should be regarded not as primordial, but as derived, that is, produced in the process of actualization and of the cancellation of difference under qualities and quantities.

It may also be repeated here that, at every step, Zhu Xi stresses the mutual immanence of different levels of actualization: "in the world there is no energy without veins, and no veins without energy (天下未有無理之氣, 亦未有無氣之理。氣 以成形，而理亦賦焉)” (Yulei 1, 2b; QS 14, 114); “in moving, energy relies on these veins, and when energy coagulates, then veins are also in it (此氣是依傍 這理行, 及此氣之聚, 則理亦在焉)" (Yulei 1, 4b-5a; QS 14, 116). Energy is the impetus of a thing or a process and the veins are its articulations.

\section{Actualized Things}

The final stage of an actualization process is the actual things and events. There are different terms for this in Chinese: $w u$ 物 “thing”, wanwu 萬物 “ten thousand things" (that is, all things), shiwu 事物 “events and things”, xing 形“"form”, $q i$ 器 "utensils" (considered in a very broad sense that every being is a "utensil" of the Dao), and others. As we saw above, already the energies belong to the "among the forms" (xingerxia 形而下); this holds even more true for the actualized things. Here, the word "form" refers to a metrical form, a being that has become

39 "Yin and yang are energies. The five phases are stuff. It is necessary to have stuff to bring out things and events. Although the five phases are stuff, they also (each) have their own energies, by means of which they make these things and events. But it is the two energies of yin and yang themselves that differentiate and produce the five phases. It is not the case that outside of yin and yang there are five phases that have a separate existence (陰陽是氣, 五行是質。有這質, 所以 做得物事出來。五行雖是質, 他又有五行之氣做這物事, 方得。然卻是陰陽二氣截做這五 箇, 不是陰陽外別有五行)” (Yulei 1, 13b; QS 14, 123). Zhu Xi also says that yin and yang take each other as a substrate or stuff: “Yin takes yang as its stuff, and yang takes yin as its stuff (陰以 陽為質，陽以陰為質)” (Yulei 1, 16a; QS 14, 125). 
spatio-temporally juxtaposed to others and temporarily stabilized; it should not be taken in the sense of form as opposed to matter.

At this final stage of actualization, the interpenetration ceases, and self-identity is formed:

"A thing is something that if it moves, then it is not still, and if it is still, then it does not move". It is called an implement among-the-forms. It is among the forms and therefore cannot interpenetrate, so that when it moves, then its stillness disappears, and when it is still, its movement disappears. Like water is just water and fire is just fire. Or in case of people, when she speaks, she is not silent, and when she is silent, she does not speak. Or in case of things, if it flies, it is not a plant, and if it is a plant, it does not fly.

‘動而無靜, 靜而無動者, 物也。’此言形而下之器也。形而下者, 則不能通, 故方其動時, 則無了那靜; 方其靜時, 則無了那動。 如水只是水, 火只是火。就人言之, 語則不默, 默則不語; 以物 言之，飛則不植，植則不飛是也。(Yulei 94, 61a; QS 17, 3160)

We see that, far from being a grounding and starting principle, self-identity is the very last "thing" to form, concealing the virtual multiplicity and putting a stop to mutual interpenetration. It is only now that water is just water, $\mathrm{A}=\mathrm{A}$, a naked repetition. Of course, this is only partially or relatively true, because there are always some processes of counter-actualization.

A person certainly has movement inside stillness and stillness inside movement; it is also called a thing. When we talk about things we refer to the fact that the form and implement has a certain rhizome-body, but it has inside itself a change and interpenetration. It must be kept in mind that an implement is also the Way and the Way is also the implement, ${ }^{40}$ no implement can be taken separately from the Way. This is the rule for all things. Like this bamboo chair here is certainly an implement, and when we make use of it, it certainly has a Way inside itself.

人固是靜中動, 動中靜, 亦謂之物。凡言物者, 指形器有定體而 言, 然自有一個變通底在其中。須知器即道, 道即器, 莫離道而 言器可也。凡物皆有此理。且如這竹椅, 固是一器, 到適用處, 便有個道在其中。(Yulei 94, 63a; QS 17, 3161-62).

40 This echoes the famous Buddhist saying from the Heart sutra that form is emptiness and emptiness is form. 
From the Western tradition, Deleuze's ontology seems to be well suited to describe the different Chinese notions for actualized things. It shows how each one of them has its supreme ultimate and veins immanent to them, as a singular entity, and also how they, to a certain extent, still interpenetrate each other. The identity of a form or of an idea is not presupposed, but forms during the process of actualization.

\section{Mutual Aid}

The Deleuzian interpretation of Zhu Xi presented in this paper can be beneficial to the research into both philosophers, and it may be useful not only in the realm of philosophy, but also as in a wider realm of cultural communication.

First, this interpretation could help to explain some classical problems in the exegesis of Zhu Xi (for instance, the relation between veins and energy, or between the supreme ultimate and veins or energy). This analysis can also be broadened to other domains of Zhu Xi's thinking, like his analysis of heart/mind ( $\mathrm{xin}$ 心), nature (xing 性) and feelings (qing 情) that are related to his ontology of veins and energy, ${ }^{41}$ or to his methods of counter-actualization, like enlargement of knowledge (zhizhi 致知), investigation of things (gewu 格物), quiet sitting (jingzuo 靜坐), seriousness (jing 敬), and others. Furthermore, a similar analysis could be applied to other Chinese philosophers that have a philosophy of differentiation as their background (that is, to most Chinese philosophers).

Deleuze's philosophy, on the other hand, would gain though this comparison new areas of relevance and at least some scholarly debates (for instance, the debate of the primacy of the virtual versus that of the intensities, mentioned in section "Status of the Veins") in Deleuzian studies could be related to debates in the Zhu Xi studies. Deleuze has already had great influence in the research into affect, embodiment and art (e.g. Sauvagnarges 2013). The new areas of relevance, opened by the connection with the Chinese tradition (e.g. intensities and $q i$ 氣), could also help to elucidate certain Deleuzian concepts (e.g. the Body-without-Organs).

Second, it can be useful for more general cultural communication and the creation of a new self-understanding. Let me provide an example. The topic of mind and body continues to be an object of heated discussions, and although it is both philosophically and scientifically clear that a strong dualism of mind and body is not a viable theory, this dichotomy still strongly influences our attitude towards

41 So that the nature corresponds to the veins, feelings to the energy and the heart/mind is an intermediary notion. This introduces the topic of subjectivity and adds further details to the scheme. 
ourselves and our bodies, towards medicine and the ways of and reasons for doing sports, yoga or tai chi, etc. As I have often found with my students, if a Westerner is pushed to make explicit her folk theories, she still tends to present some form of Platonism, with clear dichotomies of mind and body, inextensive and extensive, one and many, etc. However, upon closer scrutiny, these views turn out to be both philosophically and scientifically untenable. ${ }^{42}$

Instead, it would be more fruitful to consider our psychophysical being as a multiplicity that is simultaneously played out on different levels: virtual, intensive, actual. And if we adopt this kind of Deleuzian ontological framework we can also, with the help of the interface presented here, ${ }^{43}$ make a fruitful connection to Chinese concepts and practices. In the present paper, a bridge was built to Zhu Xi's ontology, but it may also be connected to certain practices, like wushu 武術 or qigong 氣功, which, among other notions, make use of the concept of $q i$ 氣. As already hinted above, this notion has posed serious problems to Western understanding. What is it? Is it psychological or material? This (false) dichotomy has several negative consequences. For example, if it is conceived as something material, it may give occasion to futile efforts to detect it with some apparatus. And if the apparatus fails to detect it, then it may be pronounced irreal and inexistent. On the other hand, qi may be considered as something mystical, a completely unexplainable power, which can lead to an unscientific and even anti-scientific worldview.

Instead, within the framework of a Deleuzian ontology this kind of dichotomy of mind and body disappears. There is a psychophysical multiplicity on different levels of interpenetration/juxtaposition, and qi can be considered the "energy" with which one's psychophysical reality or "veins" are actualized. It is neither physical nor psychic, nor is it psychophysical without differentiation; instead, it is both physical and psychic, yet simultaneously unfolds on different levels of interpenetration, and with varying power of actualization. In this way, for instance, taijiquan 太極拳 or qigong may help the practitioner to enhance her power of actualization, without the need to become a reductionist materialist or a reductionist mysticist.

In practical terms, it may help to overcome, on the "somatic" level, both the "cult of body", in the sense of fetishizing a certain (actualized) form of the body, and

42 Philosophically, the Cartesian dualism was immediately overcome by Spinoza's monism and has since never ceased to be overcome in various different ways (Deleuze's work may be counted among them). Scientifically let me just mention the Embodiment Theory (see Shapiro 2014) and the work of Antonio Damasio (1994), among numerous others.

And elsewhere, like in the work of F. Jullien (2004) mentioned above. 
the contrary "neglect of body" (cf. Wang 2010), and, on the "intellectual" level, both the "cult of knowledge", in the sense of idolatrizing knowledge for knowledge's sake, and the "despising of knowledge", which has spread recently in the post-factual world. What is central, are not the actualized bodily or intellectual forms (or empty and simply nihilistic reactions against them), but the "energy" to produce forms and the "veins" that are implied in them. Our main attention in self-cultivation and social practices should take place on those two ontological levels, in order to be able to create better personal and social forms. This is also related to the topic of counter-actualisation (undoing existing actual forms in order to make new ones, cf. Sholtz 2016) that I have discussed elsewhere (Ott 2019).

In order to achieve this fruitful resonance between traditions, proper philosophical work is needed, because there is no common ground between modern science and Chinese self-cultivation techniques. It is necessary to search for their ontological underpinnings, so that through their incongruity or disparity an ontological depth would open, as mentioned at the beginning of the article. With the help of this conceptual space, philosophies and practices from different traditions can be utilized.

\section{Conclusion}

In this paper, I analysed some key concepts of Zhu Xi's ontology in terms of Gilles Deleuze's philosophy. In particular, I interpreted the veins ( $l i$ 理) in terms of the virtual; the supreme ultimate (taiji 太極) in the state of "not yet emitted" (weifa 未發) in terms of the dark precursor and in the state of "already emitted" (yifa 已發) in terms of the field of individuation; the energy ( $q$ i氣) in terms of the intensities or spatio-temporal dynamisms; and the various terms for things ( $w u$ 物

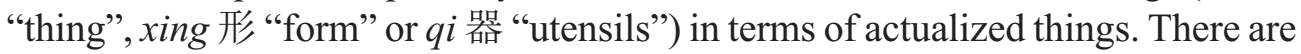
some distinctions between stages of actualization (for example, between yin-yang 陰陽 and the “five phases" wuxing 五行) that do not appear in Deleuze, and the correspondences are certainly not exact, but there is a general homology in their descriptions due to the subject matter itself, namely the logic of differentiation.

I describe Zhu Xi's account of differentiation on its different levels and aspects: (1) the veins being enveloped into (2) a supreme ultimate and unfolded from (3) the stage of not-emitted to already-emitted, (4) through the bipolar action of yin-yang and (5) fivefold interaction of the five phases to (6) the ten thousand 'coagulated' things. I then argue that it can be (re)described in Deleuzian terms of the actualization of (1) a virtual multiplicity, (2) the unfolding of differential relations and singular points, through (3) the action of a dark precursor, on (4) 
fields of individuation, through (5) spatio-temporal dynamisms to (6) actualized beings and events. Of course, it should be borne in mind that these phases are not (only) successive, but that the virtual and actual are two halves of a thing and that there are no veins or energy separated from things, and vice versa.

Finally, the potential mutual support between Deleuze and Zhu Xi was briefly laid out, both in the sphere of philosophy and in that of intercultural communication. A philosophical conceptual work can create a "space" in which one can inscribe elements from different traditions that otherwise have no common ground, and hence no relevance to each other.

\section{References}

Adler, Joseph A. 2015. “On Translating Taiji.” In Returning to Zhu Xi: Emerging Patterns within the Supreme Polarity, edited by David Jones, and Jinli He, 51-82. New York: State University of New York Press.

Ansell-Pearson, Keith. 2002. Philosophy and the Adventure of the Virtual. London, New York: Routledge.

Badiou, Alain. 1999. Deleuze: The Clamor of Being. Translated by Louise Burchill. Minneapolis: University of Minnesota Press.

Bowden, Sean. 2017. "The Intensive Expression of the Virtual: Revisiting the Relation of Expression in Difference and Repetition." Deleuze Studies 11 (2): 216-39.

Chan, Wing-tsit. 1963. A Source Book of Chinese Philosophy. New Jersey: Princeton University Press.

Chen, Chun 陳淳. 1986. Neo-Confucian Terms Explained. Translated by Wingtsit Chan. New York: Columbia University Press.

Chen, Shunfu 沈顺福. 2016. “About Zhu Xi's 'li Produces qi” 论朱喜的” 理生 气’.” Zhongguo zhexue shi 中国哲学史 (History of Chinese Philosophy) 3: 70-77.

Damasio, Antonio. 1994. Descartes' Error: Emotion, Reason, and the Human Brain. New York: Putnam.

DeLanda, Manuel. 2002. Intensive Science and Virtual Philosophy. London, New York: Continuum.

Deleuze, Gilles. 1991. Bergsonism. New York: Zone Books.

—. 1994. Difference and Repetition, (DR). New York: Columbia University Press.

Dronsfield, Jonathan. 2012. "Deleuze and the Image of Thought." Philosophy Today 56 (4): 404-14. 
Gedalecia, David. 1974. "Excursion into Substance and Function: The Development of the t'i-yung Paradigm in Chu Hsi." Philosophy East and West 24 (4): 443-51.

Graham, Angus. 1981. Chuang-Tzu. The Inner Chapters. London: Mandala.

Hallward, Peter. 2006. Out of this World: Deleuze and the Philosophy of Creation. New York: Verso.

Hughes, Joe. 2009. Deleuze's Difference and Repetition: A Reader's Guide. London: Continuum.

Jullien, François. 2004. Treatise on Efficacy. Honolulu: University of Hawai'i Press.

Kern, Iso. 2010. Das Wichtigste im Leben. Wang Yangming (1472-1529) und seine Nachfolger über die 'Verwirklichung des ursprünglichen Wissens' 致良知. Basel: Schwabe.

Lambert, Gregg. 2012. In Search of a New Image of Thought. Gilles Deleuze and Philosophical Expressionism. Minneapolis: University of Minnesota Press.

Lao-Tzu. 1993. Tao Te Ching. Translated by Stephen Addiss and Stanley Lombardo. Indianapolis: Hackett.

Leibniz, Gottfried Wilhelm. 1989 (1956). Philosophical Papers and Letters. Edited and translated by Leroy E. Loemker. Dordrecht-Boston-London: Kluwer.

Lundy, Craig. 2017. "Tracking the Triple Form of Difference: Deleuze's Bergsonism and the Asymmetrical Synthesis of the Sensible." Deleuze Studies 11 (2): 174-94.

Makeham, John. 2010. "Introduction." In Dao Companion to Neo-Confucian Philosophy, edited by John Makeham, ix-xiii. London: Springer.

Munro, Donald J. 2015. "Unequal Human Worth." In The Philosophical Challenge from China, edited by Brian Bruya, 121-58. Cambridge, Mass: MIT Press.

Needham, Joseph. 1956. Science and Civilisation in China, vol. II. "History of Chinese Scientific Thought". Cambridge: Cambridge University Press.

Ott, Margus. 2019. "Deleuze and Zhuangzi: Actualization and Counter-actualization." Asian Studies 7 (1): 315-35.

Sauvagnarges, Anne. 2013. Deleuze and Art. London, New York: Bloomsbury.

Shapiro, Lawrence, ed. 2014. The Routledge Handbook of Embodied Cognition. London, New York: Routledge.

Sholtz, Janae. 2016. "Dramatization as Life Practice: Counteractualisation, Event and Death." Deleuze Studies 10 (1): 50-69.

Sommer, Deborah. 2008. "Boundaries of the Ti Body." Asia Major 2 (3): 293-324. Tan, Sitong. 1984. An Exposition of Benevolence. Hong Kong: Chinese University Press. 
Thompson, Kirill. O. 2015. "Opposition and Complementarity in Zhu Xi's Thought." In Returning to Zhu Xi: Emerging Patterns within the Supreme Polarity, edited by David Jones, and Jinli He, 149-76. New York: State University of New York Press.

Wang, Robin. 2010. “The Virtuous Body at Work: The Ethical Life as $Q i$ 氣 in Motion." Dao 9: 339-51.

Yang, Lihua 杨立华. 2015. “Revisiting Zhu Xi's Thought on the Movement and Quiescence of $l i$ and $q i$ ” 朱子理气动静思想再探讨." Yunnan daxue xuebao (shehui kexue ban) 云南大学学报 (社会科学版) (Journal of Yunnan University (Social Sciences Edition)) 1: 53-56.

Zhang, Dainian. 2002. Key Concepts of Chinese Philosophy. New Haven: Yale University Press.

Zhu, Xi 朱喜. 2002. The Collected Works of Master Zhu 朱子全書, (QS). Shanghai: Guji chubanshe.

—. 2003. "Draft Translations of Segments from the Zhu Zi Yu-lei (Classified Conversations of Master Zhu)." Translated by Patrick Edwin Moran. http:// users.wfu.edu/moran/zzyl_TOC.html. 